\title{
Internet resources for classical studies
}

\author{
By Fred W. Jenkins and Nancy Courtney
}

\section{Ancient Greece and Rome come to life online}

\section{D}

espite their sometimes stodgy reputation, classicists have been in the forefront in taking advantage of new technologies. Classical resources on the Internet have proliferated to such an extent that only a small selection can be noted here; fortunately the self-referential nature of the Web ensures that an enterprising searcher will find nearly everything of interest from these starting points. We have focused on Web sites that provide comprehensive links to other Internet resources and/or extensive and unique collections of reference or research materials, on full-text electronic journals, and on discussion groups of reasonably wide interest. In general, we have omitted the homepages of individuals and academic departments.

\section{General sites/starting places}

- Electronic Resources for Classicists: The Second Generation. A very well organized introduction to classics resources on the Internet written by Maria C. Pantelia of the University of California, Irvine. Items are grouped by type of resource, (e.g., gateways, e-text archives, professional organizations, etc.). Access: http://www.tlg.uci.edu/ tlg/index/ resources.html.

- Classics and Mediterranean Archaeology. A collection of Internet links maintained by the University of Michigan Department of Classical Studies, it includes a helpful keyword search feature and is contained on a single Web page that users can copy. Access: http:// classics.lsa.umich.edu/.
- Resources for Classics on the Internet. A selection of links compiled by the University of Chicago. Access: http:// humanities.uchicago.edu/humanities/classics/ Resources/Net.html.

- Classics Collections Page. A compilation of Internet resources from Blake Landor of the University of Florida Library. Access: http: /nervm.nerdc.ufl.edu/ blaland/Class.html.

- Library of Congress Greek and Latin Classics Internet Resources. "Resources for Classics and certain related disciplines (Mediaeval Studies, Renaissance Studies, Patristics, etc.) on the Internet." Access: http://lcweb.loc. gov/global/classics/claslink.html.

- Repositories of Classical Texts or Publications. This selected list of classics sites by J. Ruebel of Iowa State University includes more types of material than the name implies, including resources for language study. Access: http://www.public.iastate.edu/ flng_info/Classics/resources.html

- Voice of the Shuttle: Classical Studies Page. Part of a larger site called "Voice of the Shuttle: Web Page for Humanities Research," compiled by Alan Liu of the University of California, Santa Barbara. Access: http:// humanitas.ucsb.edu/shuttle/classics.html.

- Voice of the Shuttle: Archaeology Page. Access: http://humanitas.ucsb.edu/ shuttle/archaeol.html.

\section{Specialized Web sites}

- Ancient Medicine/Medicina Antiqua. "A resource for the study of Greco-Roman medicine and medical thought" sponsored by the Episcopal Academy, this site contains bibliographies, links to articles and reviews, announcements, and hypertext versions of ancient medi- 
cal texts. Access: http://web1.ea.pvt.k12.pa.us/ medant

- Bibliotheca Classica Selecta (BCS). An annotated bibliography in French that introduces the basic literature of classics. Still under construction, it is based on the printed bibliography by J. Poucet and J. M. Hannick, Aux Sources de l'Antiquité Gréco-Romaine. Guide Bibliographique(5th ed., Namur, Belgium: Editions Artel, 1997). It is mainly a bibliography of printed works with links to available Internet sources. Access: www.fusl.ac.be/Files/General/ $\mathrm{BCS} / \mathrm{BCS}$.html.

- De Imperatoribus Romanis. This is an online encyclopedia on the Roman emperors, consisting of fairly short, peer-reviewed articles, each including an image of the emperor and a brief bibliography. Access is through alphabetical or chronological listings as well as genealogical charts of the imperial families. Construction of this site has just begun and many entries are not yet active. Access: http://www.salve edu/ dimaiom/deimprom.html.

- Diotima: Materials for the Study of Women and Gender in the Ancient World. Includes course materials, announcements, bil)liographies, links to book reviews, databases, online articles, and images. There are several search tools available. Access: www.uky.edu/ ArtsSciences/Classics/gender.html.

- Duke Papyrus Archive. A project of the Special Collections Library at Duke University to provide "electronic access to texts about and images of 1,373 papyri from ancient Egypt." There are search features available and the ability to browse by selected topics or by language. Access: http://odyssey.lib.duke.edu/papyrus/.

- NESTOR. This is a bibliography of Aegean prehistory and related areas from the University of Cincinnati. Currently, the years 1956-1995 are available online and can be

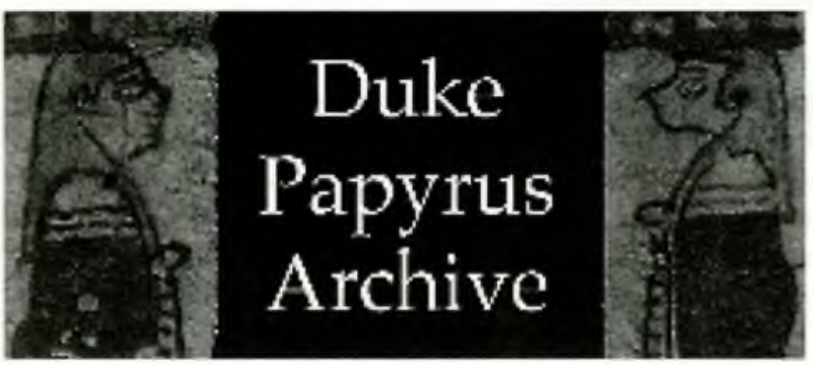

The Duke Papyrus Archive is part of the Digital Scriptorium Web site. Reproduced contesy of the Duke University Special Collections Library. searched using one of two Web-based forms. Access: http://ucaswww.mcm.uc.edu/classics/ nestor/nestor.html

- Papyrology Home Page. This page includes links to institutions with papyrology collections, images, reviews, and announcements of books on papyrology, and the table of contents and indices of Zeitschrift für Papyrologie und Epigraphik. Access: http:/ www-personal.umich.edu/ jmucci papyrology/.

- Perseus Project. A multimedia database of text, images, and information on ancient Greece (eventually to include ancient Rome). Available commercially as a $\mathrm{CD}-\mathrm{ROM}$, the free Web site includes much of the CD content (although only about 14,000 of the CD's 24,000 images). In some cases information is available on the Web site that is not yet on the CD. Perseus includes the complete works of 27 authors in Greek and English, images of art objects, sites, and buildings, an encyclopedia, and various search tools, including English and Greek word searches. Access: http://www. perseus.tufts.edu/

- Thesaurus Linguae Graecae Home Page. This site contains information about the TLG, an electronic database of ancient Greek authors. It includes general information about the project, the text of the most recent TLG newsletter, lists of authors included in the current TLG CD, and, to be included in the new version, information on licensing the database and how to have a database search done without purchasing the CD. Access: http://www. uci.edu/ tlg/.

- TOCS-IN (Tables of Contents of Journals of Interest to Classicists). Tables of contents for more than 150 journals. A search function allows you to retrieve entries by keywords, including author, title, date, and journal abbreviation. Access: http://www.chass.utoronto. ca:8080/amphoras/tocs.html.

\section{Associations}

These sites generally include descriptions of the associations, membership information, and announcements of conferences and publications.

- American Classical League. Focuses on teaching of the classics at all levels. Access: http://www.umich. edu/ acleague/

- Archaeological Institute of America. Primary American organiza- 
tion for classical archaeology. Access: http: /csaws.brynmawr.edu:443/aia.html.

- American Philological Association. Professional association for Greek and Latin scholars. Access: http:// scholar.cc.emory.edu/scripts/APA/APAMENU.html.

- American Society of Papyrologists. Access: http://scholar.cc emory.edu/scripts/ASP/ASP-MENU.html.

- Classical Association of Canada. Major organization for classical studies in Canada. Access: http://www.trentu.ca/faculty/cac/.

\section{Directories}

Web-based directories, capable of continuous updating, are an ideal solution to the problem of locating people on the move. Those noted below include classicists in North America, Europe, and Sub-Saharan Africa.

- Althistorische Institute der Bundesrepublik Deutschland. A directory of German ancient historians arranged by institution. $A C$ cess: http://ivory.trentu.ca/www/cl/brddir. html.

- CASA Directory of Classical Scholars and Research for Higher Degrees at Universities in Sub-Saharan Africa. Arranged by university, with a separate list of independent scholars. Access: http//www.und.ac.za/und/ classics/casadir/casadir.htm.

- Classical Studies in Canadian Universities. Quasi-official directory of the Classical Association of Canada. Arranged by institution, this site includes directory information for individuals and descriptions of departmental programs. Access: http://ivory.trentu.ca/www/cl/ cacdir.html.

- Classicists in British Universities: An E-Mail Directory. Alphabetical listing of British and Irish classicists; provides only e-mail addresses. Access: http://ivory.trentu.ca/www/ $\mathrm{cl}$ /ukemail.html.

- Directory of Ancient Historians in the United States. Includes members of the Association of Ancient Historians; arranged by state and institution. Access: http://ivory.trentu.ca/ www/cl/aahdir.html.

- E-Directory for the Classical Association of the Middle West and South. Alphabetical listing of members; provides institutional affiliation and e-mail address (with direct link). Access: http://falcon.cc.ukans.edu/ ophil/ camwsdir.htm.

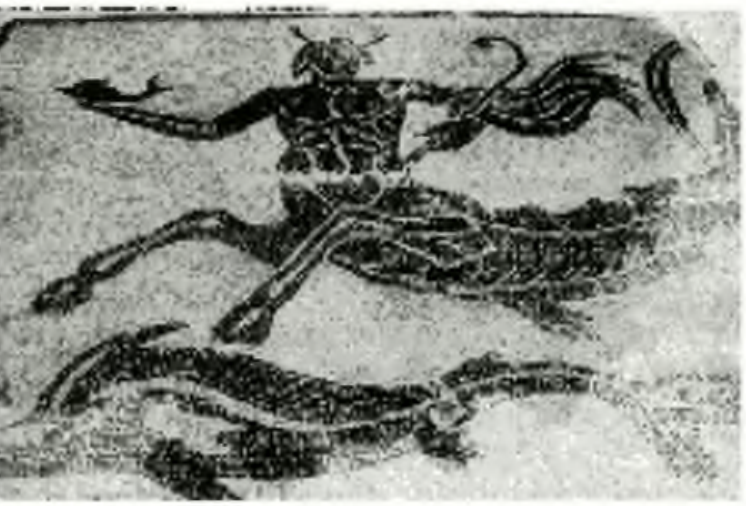

Mosaic in Roman Bath at Isthmia. Can be accessed through the Classics and Mediterranean Archaeology site and others. Reproduced courtesy of the Obio State University Excavations at Istbmia.

- Home Pages of the Classicists. Direct links to the homepages of a wide range of classicists. Access: http://aleph.lib.ohio-state.edu/ $\sim$ bcase/hoipolloi.html.

- International Directory of Aegean Prehistorians. Lists archaeologists and historians currently active in the field of Aegean prehistory. May be downloaded. Access: http:/ classics.lsa.umich.edu/IDAP.html.

- Scholars Press Consortium Membership Directory. Includes members of the American Philological Association and American Society of Papyrologists. Searchable by name, institution, and city or state. Access: http: /scholar.cc.emory.edu/cgi-bin/ph.pl.

\section{Electronic journals}

Classical scholars were among the first to establish electronic journals; some of those listed below now have been published for several years. Only full-text electronic journals are noted here; print journals that only offer contents listings online are omitted.

- Ancient History Bulletin. Short articles and notes on all aspects of ancient history. Only the more recent volumes are available in full text. Access: http://www.trentu.ca/faculty.ahb/

- Aracbnion: A Journal of Ancient Literature and History on the Web. Scholarly articles on classical literature and ancient history. Many are in various European languages, although some are in English. Access: http:// www.cisi.unito.it/arachne/arachne.html.

- Bryn Mawr Classical Review. Timely, scholarly reviews of books in all areas of classical studies. Subscribers receive reviews as published; backfiles may be browsed by go- 
pher. Subscribe: majordomo@BRYNMAWR. EDU. Access: gopher://gopher.lib.virginia. edu: $70 / 11 /$ alpha/bmer.

- Classics Ireland. Articles on all aspects of classical studies, geared towards students and general readers. Appears in both print and electronic forms. Access: http://www.ucd.ie/ classics/ClassicsIreland.html.

- Didaskalia: Ancient Theater Today. Focuses on staging and performance of ancient theater both in ancient and modern times; includes reviews of current productions. Access: http://www.warwick.ac.uk/didaskalia/ didaskalia.html./.

- Electronic Antiquity. One of the earliest electronic journals in classics, it includes articles, reviews, and conference and position announcements. A regular column notes new electronic resources. Announcements of new issues, with tables of contents, are sent to those who send a subscription request to antiquityeditor@classics.utas.edu.au. Access: gopher:// info.utas.edu.au/11/Publications/.

- Scholia Reviews. Reviews of scholarly books in classical studies. Subscribers receive reviews as they become available; backfiles are available on the Web. Subscribe: scholia@ owl.und.ac.za. Access: http://www.und.ac.za/ und/classics/elecrev.html.

\section{Electronic text repositories}

A number of sites offer classical texts in either the original or English translation. Relatively few Greek texts are available (most through Perseus, which is noted above in Specialized Web Sites). The texts are mainly taken from older editions which are now in the public domain; their quality varies radically.

- Alex: A Catalog of Electronic Texts on the Internet. Includes a number of standard classical authors in English translation. Offers both browsing and search features. Maintenance of the site has been suspended for the present. Access: http:/www.lib.ncsu.edu/staff/morgan/ alex/alex-index.html.

- CCAT Text Archives. Provides a limited selection of classical and medieval texts in English translation. Access: gopher://ccat.sas. upenn.edu: $70 / 11 /$ Archive

- Internet Classics Archive. Includes nearly 400 Greek and Roman works in English translation. Allows browsing by author. Access: http://classics.mit.edu.

- Labyrinth. This medieval studies site provides a small collection of Latin and medi- eval texts. Most are in English translation, some are in Latin, while a few are offered in both. Access: http://www.georgetown.edu/labyrinth/ library/latin/latin-lib.html.

- Oxford Text Archive. One of the largest electronic text archives, OTA includes a large collection of classical texts in the original languages. While some can be downloaded directly, access to most is restricted to varying degrees. Access: http://users.ox.ac.uk/ archive/ ota.html.

- Project Libellus. Texts of standard Latin authors available for downloading. Access: http: /osman.classics.washington.edu/libellus/ libellus.html.

\section{Discussion groups/lists}

- AEGEANET. A group for discussion and news related to the Aegean Bronze Age. This list is archived by subject line and date of posting at http://www.umich.edu/ classics/archives/aegeanet/. Subscribe: majordomo@ acpub.duke.edu.

- AlA-L. This is a discussion group operated by the Archaeological Institute of America that encompasses a broad range of archaeological issues as well as technical and computer questions. Subscribe: majordomo@brynmawr. edu.

- ANAHITA. A listserv focused on women and gender in the ancient world. Subscribe: listserv@lsv.uky.edu.

- ANCIEN-L. Devoted to the ancient history of the Mediterranean area; discussion extends to ancient Near Eastern civilizations as well as the classical period. Subscribe listserv (a) listserv.louisville.edu

- ARCH-L. A large and very active list for discussion of a wide range of archaeological topics. Subscribe listserv@tamvm1.tamu.edu.

- B-GREEK. Discussion of New Testament Greek; requires working knowledge of Greek. Subscribe: majordomo@virginia.edu.

- CLASSICS. The largest and most com prehensive discussion group for classical studies; covers all aspects of the field. List archives are available at http://weber.u.washington.edu/ rwright/classic.html. Subscribe: listproc@u. washington.edu.

- ELENCHUS. Focuses on early Christian literature (ca. A.D. 100-500). Subscribe: listserv@ listserv.uottawa.ca.

- GREEKARCH. Discussion of the archaeology of the ancient Greek world. Archives are available at http://www.umich.edu/ classics/ 
archives/greekarch/. Subscribe: majordomo@ rome.classics.lsa.umich.edu.

- GROMARCH. A joint subscription to both GREEKARCH and ROMARCH. Subscribe: majordomo@rome.classics.lsa.umich.edu.

- HOMER-L. Discussion of Homeric poetry. Subscribe: listproc@lists.missouri.edu.

- IOUDAIOS-L. Covers Judaism in the Greco-Roman world. Subscribe: listserv@ lehigh.edu.

- LATIN-L. While this list is meant to cover all aspects of Latin and NeoLatin studies, in practice it tends to focus on teaching Latin at the high school level. Subscribe: listserv@ psuvm.psu.edu.

- LEXI. Covers Greek and Latin lexicography. Subscribe: listserv@uci.edu.

- LT-ANTIQ. Focuses on the Mediterranean and Middle East in the late antique period (ca. A.D. 260-640). Subscribe: listserv@vm. sc.edu.

- MEDTXTL. Although populated mainly by medievalists, this list often covers areas important for classical studies such as palaeography and codicology. Subscribe: listserv@postoffice.cso.uiuc.edu.
- NUMISM-L. Devoted to the study of ancient and medieval coins. Subscribe: listserv@vm.sc.edu.

- PAPY. Forum for the study of papyrology; postings are often technical in nature. Subscribe: listserv@igl.ku.dk

- PERSEUS. Discussion group for users of the Perseus database. Subscribe: listserv@ brownvm.brown.edu.

- ROMARCH. Discussion of the art and archaeology of the Roman Republic and Empire, including ancient Italy and the Roman provinces. Archives are available at http:// www.umich.edu/ classics/archives/romarch/. There is also a ROMARCH homepage at http: $/ /$ WWW-personal. umich.edu/ pfoss/ ROMARCH.html.Subscribe: majordomo@rome. classics.lsa.umich.edu.

- SOPHIA. A discussion list devoted to ancient philosophy. Subscribe: listproc@liver pool.ac.uk.

- TALAROS. A very low traffic list concerning Hellenistic Greek history and literature. Subscribe:listproc@piranha.acns.nwu.edu.

- THUC-L. Discussion of Greek historian Thucydides.Subscribe. listserv@vm.temple.edu.

\section{International Materials Review}

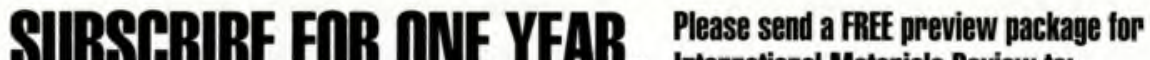

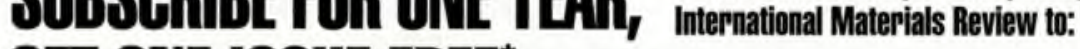 GET ONE ISSUE FREE \\ Name}

This journal provides reviews of specific materials science and metallurgy topics and contains diagrams, tables, charts, photographs and formulas that provide technical information on a wide variety of subjects.

* First-time subscribers buy one yearand get one issue FREE! Call 1-800-336-5152, or mail this coupon.

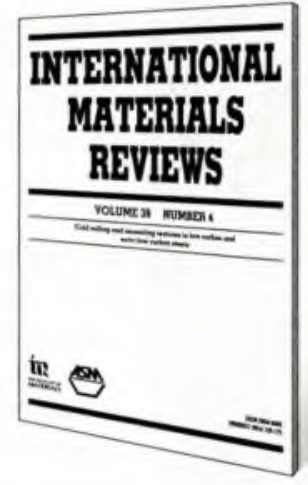

Title

Company Name

Address

City

State ZIP Country

Phone

Fax

E-mail

Mail to: Member Services Center

ASM International, Materials Park, OH 44073-0002

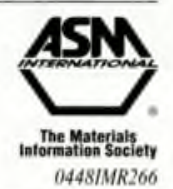

